\title{
Innovative Development Model of College Students' Education under We Media Based on Big Data
}

\author{
Zhang Fan \\ Sanquan college, Xinxiang Medical University, Xinxiang, Henan, China
}

\begin{abstract}
Innovative development of College students' education is the endogenous driving force of manufacturing development.In recent years, with the rapid development of we media technology represented by microblog and wechat, we media has become the most active main platform of network communication. In the irresistible development trend of we media, the education of college students is facing opportunities and challenges. This paper studies the innovative development model of College Students' Education under we media based on big data. This paper analyzes the characteristics of we media environment, such as the nodalization of communication subject, the interaction of communication mode, and the fragmentation of communication content. At the same time, this paper analyzes the connotation of the concept of College Students' education innovation, the concept of College Students' Ideological and political education innovation under the environment of we media, and its basic characteristics, such as the equality of education concept, the interaction of education methods, the life of education content and the era of education carrier. At the same time, it also discusses the significance of students' educational innovation in the environment of we media. The experimental data show that the new method can build a new education mode, so as to actively and effectively carry out the education and guidance of college students.
\end{abstract}

Keywords: Big data, we media, education innovation, manufacturing development, development model.

\section{Introduction}

With the development of science and technology, we media has risen quietly. The emergence of we media makes the dissemination of all kinds of information faster and more convenient, and promotes the public to enter a new era of "everyone is a microphone" [1-2]. At the same time, the popularization of communication equipment, the progress of Internet technology and the inclination of capital market also create a huge space for the rapid development of we media. In this context, the party and the state pay close attention to the development of we media [3].

As a special kind of information media, we media also has a comprehensive impact on the current college students' life and learning, and has become an indispensable part of College Students' learning and life. "We media environment has become a new environment for students' growth and development, talent training and education in Colleges and universities." [4-5]. We media environment has brought opportunities for the development of Ideological and political work in Colleges and universities. Colleges and universities can use we media platform to enrich educational content, innovate educational methods, and improve the effectiveness of Ideological and political education. But we media is a double-edged sword, we media can not get rid of the powder absorption, flow, interest oriented development mode, which leads to the uneven development of we media [6]. As the main force of highly active in we media, college students' physical and mental development is not yet mature, and their identification of we media is limited. It is inevitable that they will be affected by vulgar, erotic, rumors and other bad content. College students' Ideological and political education is also facing severe challenges [7].

In the face of opportunities and challenges, how to pursue the advantages and avoid the disadvantages, how to realize the deep combination of the traditional advantages of Ideological and political education and we media environment, explore the innovation path of Ideological and political education for college students, and strengthen

ISSN: 0010-8189

C CONVERTER 2021

Www.converter-magazine.info 
the necessity and pertinence of Ideological and political education are the important problems that the current ideological and political educators urgently need to solve. Therefore, college students' Ideological and political education needs to keep pace with the times and adapt to the new situation of we media environment. College students' Ideological and political educators should continue to consolidate and strengthen the strength of mainstream public opinion in Colleges and universities, take the new advantages of we media as the starting point, skillfully use new technologies of we media, grasp new opportunities, overcome new difficulties, and establish a complete ideological and political work system for college students, Create a new education model, build multidimensional field of education, and enhance the vitality and effect of Ideological and political education of college students in we media environment [8-9].

\section{II.Main features of we media environment}

\subsection{Communication characteristics}

In the we media environment, the dissemination of information shows the characteristics of nodal dissemination subject, interactive dissemination mode and fragmented dissemination content.

\section{(1) Nodalization of communication subject}

In the traditional media environment, the mainstream media is the leading and center of information dissemination, and the public must pass through this center if they want to obtain information. It unidirectionally transmits information to the audience, and the audience passively accepts the information. But in the we media environment, Internet technology provides more sound for individuals and maximizes the connection with the audience. Different from the traditional media, we media brings the audience into the main body of communication, and each audience is a node of the main body of information communication. This kind of nodal characteristic enables the audience to receive and disseminate information freely on the white media, and gives the ordinary audience greater discourse power. The traditional mainstream media with central development has been replaced by nodal communication subjects, realizing the equality of discourse right, and each audience has the same discourse right.

(2) The interaction of communication mode

Traditional media are unidirectional communication mode, that is, the media voice, the audience to accept, which causes the media and the audience information asymmetry, the audience can not get the information resources they want, unable to timely feedback received information, greatly limiting the communication between the media and the audience. In the we media environment, the information asymmetry between the media and the audience is broken, and each audience is the producer and participant of the information. We media realizes the interaction between the media and the audience. This communication mode can timely feedback and disseminate the information received, and the disseminator and the audience truly realize "zero distance communication", breaking the time and space limit of traditional information dissemination.

\section{(3) Fragmentation of communication content}

Traditional media pay attention to the systematicness of things, and its content and logic are more complete. However, the content released by we media is often limited by the length of time. It is more likely to express a certain point of view or vent some emotions and emotions through fragmented, sporadic and partial explanations, and the communication content tends to be fragmented. The reason for this situation is that with the acceleration of the pace of life and the development of science and technology, people have limited time to learn and think. Facing the vast ocean of information, they can only make choices. People prefer flexible and fast fragmented information. In addition, we media has a variety of presentation methods of fragmented information, which makes it easier to popularize and spread. However, it should be noted that this kind of fragmented content will also affect people's deep thinking, unable to form a comprehensive and systematic understanding of things, giving an opportunity to

ISSN: 0010-8189 
misinterpret the nature of things.

At present, we media has entered the study and life of college students in an all-round way, and its thoughts and behaviors are also affected. Education must keep pace with the times and actively adapt to the current we media environment. Compared with the traditional ideological and political education, we media education realizes realtime education, equality of teacher-student relationship and independence of students' thoughts. In the environment of we media, information collection and sharing is more convenient. Teachers can collect and organize the latest resources as teaching materials. Through we media platform, they can communicate with students and implement all-weather education, which is incomparable to traditional education. The "unequal" relationship between teachers and students in traditional ideological and political education has been broken. On the platform of we media, teachers and college students can interact equally, students' sense of autonomy and subjectivity has been enhanced, and educational activities tend to be free and interactive. Students are no longer unable to speak as before. They can respond to educational information on the platform of we media, express their own unique views on educational content and mode, and enhance their awareness of independent thinking. Therefore, under the environment of we media, college students' education must be innovated to help them establish firm political beliefs, develop positive self-consciousness and form correct values, so as to improve the pertinence and effectiveness of education.

\subsection{The basic characteristics of College Students' educational innovation in the environment of we media}

To seek the innovation of College Students' Education in we media environment is actually a drastic reform of traditional college students' Ideological and political education in status, mode, concept, carrier and other aspects in order to conform to the development trend of college students in we media environment. It requires to realize the equality of education status, the interaction of education mode, and the innovation of Ideological and political education The diversification of educational concepts and the advanced nature of educational carriers are the inevitable stages of modern education's improvement, deepening and development.

\section{(1) The equality of educational ideas}

We media is easy to operate and has low access rules, so it is convenient for the public to spread information and express their views freely and comprehensively. The public is no longer the information controlled, but quickly become the main body of we media communication. Every individual of all social strata is the information creator and disseminator, and also the information receiver and editor. In the network environment, every we media member is not only the focus of creating and disseminating information in we media network, but also the key connecting point of rapid and effective dissemination of information in we media network. Every individual has the right to register and open his own we media account voluntarily. At the same time, he has the equal right to edit, process his own speech and disseminate information. In the environment of we media, the unequal information relationship between teachers and students is broken. Both students and teachers are the users of information, and the information resources occupied by students are equal to or even more than teachers. In this situation of information equivalence, students are more eager to have an equal dialogue with teachers. Therefore, under the environment of we media, the innovation of College Students' education must be based on the current education environment, update the concept of education, realize the equal status of teachers and students in the process of education, carry out equal communication and interaction, so as to continuously ensure the effect of College Students' Education.

\section{(2) The interaction of educational methods}

We media breaks the space-time limit of information dissemination, and its nodal dissemination mode makes the dissemination of information more rapid. In the we media environment, everyone can publish information, share information, get other people's reply anytime and anywhere, and also selectively pay attention to the we media 
dynamics of other participants, and freely participate in the dynamic communication of others. We media information dissemination has achieved equal interactivity, gradually covering the traditional upper and lower levels of communication, improving the speed of information dissemination network extension. In the environment of we media, the way of College Students' education must also adapt to the development of the times. In the process of education, both teachers and students are the owners of information. Teachers and students can interact in the educational environment created by we media to transmit information in real time and improve the effect of education.

\section{(3) Life oriented education content}

From the perspective of the popularity of we media information release, the content of information release is mainly dominated by public concerns, rather than the lack of freedom like traditional media. The public can create and disseminate information according to their own wishes. In the process of College Students' Education in the we media environment, there is an equal and mutual respect relationship between teachers and students. In order to achieve equal and effective interaction between teachers and students, we must update the traditional teaching content. Educators should collect more materials and content related to college students' life, and use pictures, videos and other easily accepted ways to transfer knowledge and information, so as to let educators walk into the middle of students, make ideological and political education content come from students' life, close to students' life, return to students' life, and enhance the affinity of College Students' Education in the we media environment.

\section{(4) The epochal nature of education carrier}

The media relies on the mobile Internet, especially the wide application of mobile app. Users have stronger voice and more independent space. Users can freely weave their own communication network, which is basically unrestricted. At the same time, we media users can spread information to the audience at the first time, which greatly improves the immediacy of information. There is almost no time difference between we media and the audience, and the audience can give feedback to the received information at the first time. Therefore, college students can use we media as an educational carrier to receive information freely and actively create and transmit information at the first time. Educators can also conform to the trend of the times, make full use of we media as an educational carrier, and show the epochal nature of College Students' education.

\section{The experiment results}

(1) T-test

T-test showed that there were significant differences in the scores of boys and girls in the four subscales of EPQ (all P < 0.05). The scores of boys in E and $\mathrm{N}$ subscales were significantly lower than those of girls, while the scores in $\mathrm{P}$ and 1 subscales were significantly higher than those of girls (see Table 1).

Table 1 Comparison of EPQ scores between men and women

\begin{tabular}{|l|l|l|l|l|}
\hline Subscale & Male & Female & $\mathrm{t}$ & $\mathrm{P}$ \\
\hline $\mathrm{E}$ & $53.56 \pm 10.92$ & $54.76 \pm 10.11$ & -2.490 & 0.013 \\
\hline $\mathrm{N}$ & $38.07 \pm 12.19$ & $42.77 \pm 10.62$ & -8.948 & 0.000 \\
\hline $\mathrm{P}$ & $42.46 \pm 5.51$ & $41.77 \pm 7.66$ & 2.333 & 0.020 \\
\hline $\mathrm{L}$ & $50.05 \pm 8.41$ & $48.61 \pm 8.30$ & 3.794 & 0.000 \\
\hline
\end{tabular}

(2) UPI results were compared with EPQ subscales 
Table 2 Comparison of EPQ scores among three groups of UPI

\begin{tabular}{|l|l|l|l|l|l|}
\hline Subscale & First kind & The second category & The third category & F & P \\
\hline E & $53.26 \pm 10.64$ & $53.71 \pm 11.10$ & $54.39 \pm 10.39$ & 1.625 & 0.197 \\
\hline N & $43.11 \pm 13.50$ & $41.53 \pm 11.45$ & $38.84 \pm 11.31$ & 19.88 & 0.000 \\
\hline P & $43.05 \pm 7.04$ & $42.37 \pm 7.20$ & $41.90 \pm 6.10$ & 3.766 & 0.023 \\
\hline L & $47.71 \pm 8.30$ & $49.15 \pm 8.80$ & $49.93 \pm 8.20$ & 8.285 & 0.000 \\
\hline
\end{tabular}

The scores of EPQ subscales of three types of people detected by UPI were analyzed by variance, and the results are shown in Table 2. The scores of the three groups of people on E and L subscales of EPQ scale gradually increased, while the scores on $\mathrm{N}$ and $\mathrm{P}$ subscales gradually decreased. There are significant differences among the three groups in the scores of $n, p$ and 1 subscales. Results Compared with LSD, the scores of neuroticism in the third group were significantly lower than those in the first and second groups $(\mathrm{P}<0.001)$. The mental quality scores of the first group were significantly higher than those of the third group $(\mathrm{P}<0.001)$. In concealment, the concealment of the first group was significantly lower than that of the second group $(\mathrm{P}<0.05)$ and the third group $(\mathrm{P}<0.01)$.

\section{(3) Comparison of EPQ subscales among students with or without suicidal ideation}

Through t-test, it was found that the scores of $\mathrm{N}$ and $\mathrm{P}$ subscales in EPQ scale of students with suicidal ideation in UPI were significantly higher than those of students without suicidal ideation $(\mathrm{P}<0.01, \mathrm{P}<0.05)$, as shown in Table 3.

Table 3 Comparison of EPQ scores between students with and without suicidal ideation

\begin{tabular}{|l|l|l|l|l|}
\hline Subscale & Have suicidal ideation & No suicidal ideation & $\mathrm{t}$ & $\mathrm{P}$ \\
\hline $\mathrm{E}$ & $50.71 \pm 12.07$ & $54.18 \pm 10.57$ & -1.567 & 0.127 \\
\hline $\mathrm{N}$ & $47.06 \pm 13.76$ & $42.77 \pm 10.62$ & 2.860 & 0.008 \\
\hline $\mathrm{P}$ & $44.78 \pm 6.79$ & $39.95 \pm 11.71$ & 2.160 & 0.039 \\
\hline $\mathrm{L}$ & $47.31 \pm 8.85$ & $49.47 \pm 8.38$ & -1.35 & 0.000 \\
\hline
\end{tabular}

\section{The implementation of College Students' educational innovation in the environment of we media}

\subsection{Principles of College Students' educational innovation in the environment of we media}

Under the environment of we media, the educational innovation of college students should follow the principles of combining inheritance of tradition with development and innovation, combining leading education with diversified education, and combining personality development with overall development.

\section{(1) The principle of combining inheritance with development and innovation}

The innovation of education should not only be based on social development and educational practice, but also inherit and develop the traditional educational thoughts and ideas. In order to innovate college students' Education in we media environment, we must inherit the excellent traditional education idea and develop and innovate it in combination with education practice. On the one hand, in the environment of we media, colleges and universities and teachers should realize that the education in we media environment is the extension and development of traditional education in we media environment, and can not completely get rid of the traditional idea of ideological education. Traditional education contains many excellent educational ideas. Therefore, in the process of education, 
teachers should combine the advantages of we media platform and the current ideological and behavioral characteristics of college students, and effectively integrate the excellent achievements and successful experience of traditional education into the current education in the we media environment. On the other hand, on the basis of inheriting the excellent achievements of traditional education, we should combine the characteristics of we media to innovate the educational concept and mode. Colleges and universities should organically combine the traditional education mode with the education mode under the environment of we media, innovate on the basis of inheriting the traditional excellent education ideas and methods, pay attention to the education needs and subject consciousness of college students, and give full play to the positive role of we media. At the same time, schools and teachers can also release education information in time through we media platform, conduct real-time interactive communication with students, understand students' needs, cultivate students' independent consciousness and main ability, so as to achieve the set goal and expected education effect of College Students' Ideological and Political Education under we media environment, and promote the development of educational innovation practice.

(2) The principle of combining leading education with pluralistic education

"The teaching of Ideological and political course can not be separated from the guidance of teachers, but at the same time, we should also add the research on the cognitive law and acceptance characteristics of college students, so as to play the main role of students." We media is a double-edged sword. We media platform is not only full of effective information of education, but also full of all kinds of wrong ideas and values. When college students use we media, they are unavoidably lack of the ability to identify information. They are easily affected by these wrong ideas and negative ideas and lose themselves. Educators in Colleges and universities must be aware of the complexity of the education environment under the we media environment, and effectively identify the wrong ideas and values on the we media platform will have a positive effect on the effective development of the current college education. Therefore, in the we media environment, we should not only focus on the socialist core values leading education, but also carry out diversified education. On the one hand, all kinds of wrong ideas and values have infiltrated into the we media environment, which has impacted and influenced our mainstream value education. In the process of education, educators should "use the achievements of the information revolution, promote the integration and development of the media, and enlarge the mainstream public opinion", constantly play the leading role of education, integrate the socialist core value system into the education information of we media, and use we media as a communication platform to carry out mainstream value education for college students, We should use the socialist core values to eliminate all kinds of wrong ideas and values in the west, guide students to identify with the core values, and firmly grasp the initiative and leading power of Ideological and public opinion. On the other hand, the current development of Ideological and cultural field presents a diversified trend. On the open we media platform, college students can learn and absorb excellent ideas and achievements at all times and in all countries. Therefore, we should fully respect the dominant position of students, actively do a good job in positive guidance, let them learn to resolutely resist in the face of all kinds of wrong ideas and negative thoughts, and consciously use the dominant position of socialist core values to meet the challenges. Therefore, in the we media environment, we should give full play to the leading role of teachers and the subjectivity of students, take the socialist core values as the leading role, and use the leading education to guide the diversification of values.

\section{(3) The principle of combining individual development with overall development}

Education should be suitable for both personal development and social goals. Traditional education focuses on the overall development of people, that is, the development of individuals should be in line with the overall development. This mode of education highlights the students' social integrity, but ignores the students' personality development. But in the environment of we media, students' subjective consciousness is gradually awakened, they prefer to pursue personalized things, in the process of education, they hope to be paid attention to, hope to improve the subjectivity and personalized education, which challenges the traditional single education mode. Education serves people, and the development of education must focus on the needs of students. Therefore, in the environment of we media, we must carry out the education of personality development and overall development

ISSN: 0010-8189 
according to the characteristics of students' growth and development and the basic laws of education. On the one hand, we media will enhance students' subjective consciousness and improve their autonomy in the face of educational information processing. They are eager for independence and equality. Universities and educators must focus on students' real needs, create personalized education mode for students, carry out personalized education for different students, and carry out flexible education according to students' different needs, So as to improve students' learning autonomy and enthusiasm. On the other hand, human nature is the product of socialization. Colleges and universities serve college students, but they must also serve the society and train qualified builders and reliable successors for socialism. Therefore, schools should pay attention to students' all-round development and meet the social needs while carrying out personalized education for students. Third, in the environment of we media, colleges and educators should set up the overall situation awareness, start from the overall situation of education, carry out the overall education and the overall situation view education for students, so that they can realize their important position in the society, establish the sense of serving the society, and cultivate the spirit of dedication to the country.

\subsection{The main contents of College Students' educational innovation in we media environment}

In the environment of we media, we should strive to realize the renewal of educational ideas, educational resources and educational space, so as to enrich the content of ideological education for college students, and reflect its epochal nature and affinity.

\section{(1) Taking we media as the guide to set up a new concept of Education}

Good educational ideas can provide useful reference for educational activities, let educators know what to teach and how to guide students' development. The innovation of educational ideas should not only conform to the trend of education, but also follow the law of education. Therefore, in the environment of we media, education must be in line with the current new situation of education, and combined with educational ideas, gradually improve and update in educational practice, realize the scientificity and epochal nature of educational ideas, and promote the innovative development of education. On the one hand, universities and educators should correct the cognitive concept of we media. We media era has come, college students' life and learning and we media have been inextricably linked, this is an inevitable trend of the times, but also we must face the objective fact. Therefore, universities and educators should face up to we media, rationally analyze its advantages and disadvantages, and make use of its advantages to play a positive role in college students' education. Universities and educators should make full use of educational resources, change educational ideas and teaching methods, and make use of we media platform to create a new position of education. On the other hand, educators should establish the concept of equal education. In the environment of we media, educators and students realize the basic symmetry of information. Everyone plays multiple roles in it, and students can also become producers and transmitters of information. Due to the equal amount of information between teachers and students, students are eager to have equal interaction and communication with teachers, hoping that the teaching environment will be more open, teaching resources will be more sufficient, and the relationship between teachers and students will be more democratic and harmonious. In this context, educators should improve their understanding of we media, pay attention to the collection, analysis and processing of effective information, make effective use of we media, abandon the simple didactic education, and communicate with students more openly and equally on the platform of we media, so as to guide college students to get rid of passive learning and cultivate the ability of information identification Independent thinking ability and autonomous learning ability.

\section{(2) Enriching educational resources through information sharing}

In the environment of we media, the storage and transmission of information is more convenient, which contains a large amount of educational information and educational resources. However, due to the fact that we media is a node communication mode, the distribution of information resources is not systematic and appears scattered. 
Therefore, in order to achieve the purpose of education, universities and educators should integrate the scattered educational resources on we media and give full play to these resources. On the one hand, colleges and universities should use we media platform to integrate educational resources. Only by sharing educational resources can we better promote the development of educational practice. As an open and shared educational platform, we media brings rich educational resources to facilitate the integration of resources between universities and ideological and political teachers. In the process of teaching, ideological and political teachers should make full use of the interactivity of we media, through microblog, wechat, wechat, wechat, etc QQ and other forms of we media communicate with students. On the platform of we media, teachers should upload their own teaching materials and teaching experience, and encourage students to upload their own learning materials and learning experience, so as to realize the sharing of resources in the communication between teachers and students. On the other hand, colleges and universities should integrate educational human resources as much as possible. Teachers are the foundation of educational activities, and teachers are the foundation of educational activities. Colleges and universities must first strengthen the construction of educational teachers, so as to lay the foundation of human resources for educational innovation in the environment of we media. Therefore, colleges and universities should not only strengthen the recruitment and introduction of professional and technical talents of we media, enrich the team of we media teachers, but also increase the training of we media skills for ideological and political educators in our school, so as to enhance their ability of we media application. At the same time, in order to improve our media application skills, colleges and universities can also organize teachers to use our media skills competition, so that teachers can improve our media application skills in mutual exchanges and exchanges. Colleges and universities should encourage educators to use we media as much as possible to carry out education, take the initiative to communicate with students, and expand the influence of personal we media, so as to make the coverage of education larger and improve the effectiveness of education.

\section{(3) Expand new space of education based on we media}

As a kind of virtual space, white media space is free and open, containing massive information resources, low cost and interactive, which attracts many college students. Therefore, to carry out educational innovation in the environment of we media, college students educators must pay attention to and make good use of the virtual space of we media, take it as a new position of education, and strive to build a new educational space with high participation of teachers and students, strong atmosphere and safety. On the one hand, colleges and universities should conform to the development trend of we media environment and strengthen the construction of we media platform. It is necessary to make full use of the hot public opinions released and transmitted by the official we media of the school in real time, and constantly strengthen the appeal of the we media platform. College educators should also take the initiative to integrate into the we media environment, create a mainstream public opinion atmosphere in the natural and vivid context, enhance students' sense of identity, enhance the effectiveness of education, and guide students to establish correct moral values and world outlook. At the same time, colleges and universities should also strengthen the construction of we media and increase capital investment to provide a strong guarantee for the construction of we media platform. It is also necessary to integrate the human, financial and physical resources of the whole school, mobilize all the school organs, teachers and students, and work together to establish a refined, systematic and safe we media education platform, so as to provide assistance for the innovation and development of College Students' education. On the other hand, college students' educators should take the initiative to strengthen our media literacy. We should enhance the awareness of we media education, recognize the important role of we media in the education of college students, change the concept of education, actively strengthen the study of we media application skills, learn to use we media flexibly in the process of education, and give play to the positive role of we media in the process of education. Educators should also establish the concept of lifelong learning, keep up with the pace of the times in educational practice and life practice, consciously use we media, constantly improve the ability and level of using we media in practice, and transfer this ability and level to educational activities. In the we media environment, students are eager to interact and communicate with educators on the we media platform, while teachers need to pay attention to the real needs of students, build a personal we media platform, publish as much as possible positive energy content with times and interest on the personal we 
media platform, actively communicate with students, actively participate in the interaction of students, and listen to the voice of students, Strive to improve the effect of Ideological and political education and guide the healthy growth of college students.

\section{Conclusion}

Everything has two sides. To strengthen the innovation of College Students' Education in the environment of we media, we must face the challenges and seize the good development opportunities, continue to ensure the effectiveness of College Students' education, and ensure the realization of the fundamental task of education that college students become socialist builders and successors. Based on the existing research results, this paper analyzes the meaning, characteristics and significance of College Students' educational innovation in we media environment, and summarizes the current situation, opportunities and challenges of College Students' educational innovation in we media environment combined with empirical research. On this basis, this paper discusses the goals, principles, methods and methods of College Students' educational innovation in we media environment Content and approach.

\section{References}

[1] Feng Gang. Study and Implement the Spirit of the 18th Cpc National Congress and Strive to Improve the Quality of I\&P Education for College Students. Journal of Ideological and Theoretical Education, 2013, 2: 44-49

[2] Zhao Jiefang, Li Haipeng. Striving to Establish the Organizational Guarantee and Long-term Mechanism of I\&P Education for College Students -- a Survey Report on the Construction of College Counselors and Class Teachers. Journal of National Institute of Education Administration, 2006 (02): $75-82$

[3] Wang Dongli. Construction of Content System of Humanistic Care in I\&P Education. Teaching and Research, 2005, V (2): 85-90

[4] Liu Mei. Modern Ways of I\&P Education -- on the Construction of Network I\&P Education. Journal of Henan Normal University (philosophy and Social Sciences), 2000 (02): 103-106

[5] Fang Hongjian, Du Liang. Analysis of I\&P Education of College Students Based on Microblog. Journal of the National Institute of Education Administration, 2011 (01): $52-55$

[6] Wang Kai. New Challenges of New Media to the I\&P Education of "post-90s" College Students. Ideological Education Research, 2010, 1: 71-74

[7] Zhang Yaocan. Analysis of the Characteristics and Laws of I\&P Education. Ideological and Theoretical Education, 2005, 2: 4-10

[8] Zheng Yongting. on the Essence and Development of I\&P Education. Teaching and Research, 2001 (3): 49-52

[9] Huang Zhengquan, Wang Jian. Humanistic Care: the Soul of I\&P Education. Modern University Education, 2007, 3: 57-60

[10] Zheng Yongting. Contemporary Issues Faced by I\&P Education in Colleges and Universities. China Higher Education, 2003, 21: 13-14 